\title{
The Indochinese Refugee Movement and the Subsequent Evolution of UNHCR and Canadian Resettlement Selection Policies and Practices
}

\author{
MICHAEL CASASOLA ${ }^{*}$
}

\section{Abstract}

The Indochinese refugee movement cast a long shadow over subsequent resettlement operations. UNHCR has since asserted greater leadership, with resettlement becoming more individually focused and globally diverse, but also more complex. Canadian policy has also evolved to become increasingly focused on protection and supportive of UNHCR's durable solution activities.

This article seeks to compare UNHCR and Canadian resettlement selection policy and practice in place during the time of the Indochinese movement up to mid-2015. It highlights key elements in the evolution of UNHCR and Canadian resettlement policy and the factors behind them. It also identifies aspects of the Indochinese movement that are relevant to contemporary refugee policy.

\section{Résumé}

Le mouvement indochinois des réfugiés a exercé une influence profonde sur les initiatives subséquentes de réinstallation. Le HCR s'est affirmé davantage à la suite en tant que chef de file dans ce domaine, avec une approche à la réinstallation de plus en plus individuelle ainsi que diversifiée à l'échelle mondiale, mais aussi plus complexe. Les politiques canadiennes ont également évolué vers la protection comme principe fondamental, ainsi que le soutien des solutions durables promulguées par le HCR.
Cet article a pour objectif de comparer les politiques et pratiques de sélectionnement en matière de réinstallation de la part du HCR et du Canada à partir de l'époque du mouvement indochinois jusqu'à la première moitié de l'année 2015. Il souligne les éléments clés dans l'évolution des politiques et pratiques de réinstallation de la part $d u$ HCR et du Canada, ainsi que les facteurs qui les ont influencés. Il identifie également les aspects du mouvement indochinois qui sont pertinents aux politiques contemporaines en matière de réfugiés.

\section{Importance of the Indochinese Movement for Resettlement Internationally and for Canada}

$\mathrm{R}$ esettlement is an important part of Canada's response to the global refugee population. Canada has always been an immigration country, but the Immigration Act of 1976 for the first time explicitly included the goal of "upholding Canada's humanitarian tradition by welcoming refugees." The structure of Canada's refuge programs was set out in the Act, which also ensured the engagement of Canadian civil society in resettlement through the establishment of a private sponsorship of refugees (PSR) program. However, Canadian resettlement has undergone a series of revisions and updates from the time it came into force in 1978 until mid-2015. The changes were sometimes linked to larger reform measures, but at other times made in isolation.

* The views expressed in this article are those of the author and do not necessarily reflect the views of UNHCR. 
The refugee protection environment has undergone continuous change over this same period, with new challenges in forced displacement, a litany of new conflicts, entrenchment of conflicts that began decades ago, and the increased inability to find solutions. Resettlement has been presented as one means to address some of these challenges. It has also been presented in some schemes as a legal pathway to respond to mixed migration flows.

Resettlement functions as a tool of protection, providing a durable solution and international responsibility-sharing and is one piece within a broader protection regime. ${ }^{2}$ Under the auspices of the Office of the United Nations High Commissioner for Refugees (UNHCR), it has undergone refinement and reinvigoration since the time of the Indochinese movement. This article follows the evolution in both UNHCR and Canadian resettlement selection policy from the time of the Indochinese movement to mid-2015. It highlights key developments and notes how some elements from the Indochinese era are once again relevant.

The resettlement of Indochinese refugees was a defining movement for refugee resettlement, both internationally and for Canada. Almost two million Indochinese were resettled between 1975 and 1997 from countries of first asylum and through orderly departure programs (legal emigration from the source country). ${ }^{3}$ Canada alone resettled over 200,000 Indochinese during this period. 4 The offers of large-scale resettlement ultimately brought an end to the pushback of Vietnamese boats and ensured those fleeing Vietnam access to asylum. 5 While the vast majority went to the United States, Canada, Australia, or France, a large number of countries were involved in resettling Indochinese refugees. ${ }^{6}$ Their collective efforts demonstrated the ability of states to work together to resolve a large-scale refugee crisis through resettlement. With the establishment of the Comprehensive Plan of Action (CPA), ${ }^{7}$ resettlement became part of a protection framework that included refugee status determination, resettlement of recognized refugees, returns of refused asylum seekers, and an orderly departure program.

The movement also highlighted some of the critiques of resettlement. The availability of resettlement was viewed by 1988 as a "pull factor" involving both refugees and economic migrants. ${ }^{8}$ Although there were other refugees around the world with needs for serious protection and durable solution that could have been resolved through resettlement, this durable solution was virtually reserved for the Indochinese, as it was not until 1993 that Vietnamese made up less than half of all those resettled globally. ${ }^{9}$ The reality that those being resettled were fleeing communist states was consistent with the critique that resettlement was effectively a Cold War instrument. ${ }^{10}$ The perceived automatic resettlement of Indochinese asylum-seekers arriving over many years led to a malaise about resettlement inside UNHCR. Many staff began feeling that although this movement enabled access to asylum, UNHCR's work in resettling Indochinese refugees was more akin to that of a travel agency than a protection agency. ${ }^{11}$

For Canada, the Indochinese movement was well timed. A decade earlier Canada had removed race as a factor in immigration selection and had signed the 1951 Refugee Convention and the 1967 Protocol. The implementation of the 1976 Immigration Act introduced a more transparent resettlement framework. It also enabled the creation of designated classes, ${ }^{12}$ giving Canadian officials the ability to apply a lower threshold in selecting members of a designated group for resettlement. In Canada, individuals and groups were so moved by the plight of the Indochinese that they not only advocated for government action, but also organized a public response encouraging Canadians "to rescue" the Indochinese through the private sponsorship program. This movement was facilitated by an interested media and a government who welcomed the opportunity to tap into the public concern of Canadians. ${ }^{13}$ The spirit of volunteerism and the large numbers eventually resettled to Canada were recognized in 1986 when the "People of Canada" were awarded the Nansen Medal, the only time the medal has been awarded to the people of a country.

\section{The Evolution of Resettlement and UNHCR's Increased Leadership Role}

In the decades prior to the Indochinese movement, the international community already had experience working together to offer resettlement as part of the response to a select number of refugee crises, mainly in Europe. As noted, while the Indochinese refugees dominated resettlement internationally for some time, the view of resettlement evolved while this movement was effectively winding down. This was noted in the 1994 evaluation UNHCR undertook to review the implementation of its resettlement policy and practice:

The scale of resettlement activities has changed dramatically over the last decade and a half. In 1979, at the peak of the refugee outflows in South East Asia, resettlement was viewed by most, if not all parties concerned, as the only viable durable solution for approximately 1 in 20 of the world's 5-6 million refugees. In 1993, this ratio had fallen dramatically to just 1 in 400 . Despite a quadrupling of the world's refugee population in the interim, this represents a significant drop in the absolute number of UNHCR cases being resettled, from over 200,000 a year in the late 1970 s to $50-60,000$ a year in the mid-199os. At the same time, major resettlement countries have focussed their efforts on other refugee and refugee-like caseloads, and not those cases identified by UNHCR. ${ }^{14}$ 
The evaluation underscored the fact that a large part of resettlement taking place globally did not involve UNHCR, and that state selection was not always on the basis of the refugee definition. Where UNHCR was involved, questions were raised about the quality of submissions. ${ }^{15}$

The ideas in the evaluation set the course for resettlement for the next few years. While critical of UNHCR in some aspects, it also affirmed that governments were increasingly looking to UNHCR for direction on resettlement. Among the resulting initiatives was a reaffirmation of UNHCR's leadership on resettlement with the support of resettlement states, including the formal endorsement of the resettlement criteria outlined in the 1996 Resettlement Handbook. The Working Group on Resettlement and the Annual Tripartite Consultations on Resettlement were established as the forums to engage multilaterally on resettlement. Furthermore, as part of UNHCR's leadership, its headquarters redirected their efforts into policy oversight, training, and tools development.

In 1999 evidence arose concerning widespread malfeasance relating to the refugee status determination and resettlement process in UNHCR's office in Nairobi. ${ }^{16}$ The December 2001 report on the investigation conducted by the UN Office of Internal Oversight Services concluded that there was a largescale criminal network involving UNHCR and non-UNHCR staff who demanded and received money to enable refugees and others to emigrate from Kenya to Australia, Canada, the United Kingdom, and the United States. ${ }^{17}$ The report, which made a number of technical recommendations in order minimize opportunities for malfeasance in the future, helped place a new impetus on resettlement program integrity and combatting malfeasance, including improved management controls and accountability. ${ }^{18}$ This trend continued with the establishment baseline standard operating procedures ${ }^{19}$ and measures to address fraud. ${ }^{20}$

These tightened controls coincided with increased state focus on security screening following the 11 September terrorist attacks, resulting in new barriers and challenges for some refugees to access resettlement. It is difficult to truly quantify the full impact of security restrictions on access to refugee resettlement, since resettlement is a voluntary activity of states, and UNHCR offices may temper their resettlement referrals, on the basis of which states are willing to consider and logistically able to resettle. Overall, it is clear that, following 11 September, security concerns have presented a significant barrier to the resettlement of some refugees. This was most evident in the United States, whose 2001 Patriot Act included provisions barring persons who were defined as providing "material support" to terrorism, resulting in "thousands of refugees in need of urgent protection ... being put on hold for the us Refugee Program due to the expanded definition and over-broad application of the material support bar."21

In Canada, the 2002 Immigration and Refugee Protection Act (IRPA) also included a number of security-related inadmissibility provisions. Section 34-which bars individuals who are "a member of an organization that there are reasonable grounds to believe engages, has engaged or will engage in acts" 22 "of subversion against a democratic government, institution or process as they are understood in Canada"23 - was a concern for advocates, since the related screening had resulted in, at the very least, slow processing for some refugees being considered for resettlement. ${ }^{24}$

Security concerns have also meant restrictions on travel for the safety of government officials affected their ability to conduct face-to-face selection of refugees for resettlement, the result being that some refugees cannot benefit from resettlement simply because of where they are located. ${ }^{25}$

The next steps in the evolution of resettlement can be linked to UNHCR's Global Consultations on International Protection, launched in July 2000 to revitalize the international protection regime and commemorate the 5oth Anniversary of the 1951 Refugee Convention. The consultations engaged refugees, governments, IGOs, NGOs, and legal experts on the greatest challenges facing refugee protection at the time. The result was the Agenda for Protection, which was endorsed by the Executive Committee of UNHCR in October 2002. While not legally binding, the Agenda for Protection proposed six goals to guide concrete action. ${ }^{26}$ "Goal 5: Redoubling the search for durable solutions" sought to invigorate all three durable solutions: voluntary repatriation, local integration, and resettlement. One objective was "expansion of resettlement opportunities":

- Make resettlement more available globally in terms of diversifying the composition of the refugees selected for resettlement

- Expand the number of refugees resettled overall

- Increase the number of resettlement countries

- Use resettlement strategically ${ }^{27}$

Strategic use of resettlement was proposed to help unlock solutions for a greater number of refugees beyond those resettled. It was defined as "the planned use of resettlement in a manner that maximizes the benefits, directly or indirectly, other than those received by the refugee being resettled. Those benefits may accrue to other refugees, the hosting State, other States or the international protection regime in general." 28

A key impetus behind this initiative was increased concern about the number of refugees living in protracted refugee situations or what was described as "warehousing refugees." 29 The hope was that resettlement might be used in combination with other solutions to provide comprehensive 
solutions to refugee situations. Canada was an important proponent and facilitated the Convention Plus Core Group on the Strategic Use of Resettlement. In June 2004 the Core Group released the Multilateral Framework of Understandings on Resettlement as a tool to guide parties on situationspecific multilateral agreements to design comprehensive arrangements in resettlement operations.

These developments added to the pressure on UNHCR to expand resettlement activities by increasing the number of resettlement case submissions from a greater number of locations, while also dedicating additional resources to strengthen program integrity. This pressure was particularly pronounced from larger resettlement countries, who require thousands of individual resettlement submissions to meet their resettlement arrivals targets-which the United States increasingly linked to UNHCR submissions. $3^{\circ}$ UNHCR therefore also faced the practical challenge of making enough resettlement submissions for states to meet their resettlement targets. The reality was that UNHCR resettlement submissions were well below the number of spaces made available for resettlement.

In order to address the realities of protracted refugee situations, and to expand the number of resettlement submissions, UNHCR developed a group referral methodology. This approach is meant for situations where there are a sizeable number of refugees with a common refugee claim and a common durable solution need. Rather than completing individual Resettlement Registration Forms (RRF), ${ }^{31}$ UNHCR instead simply submits registration information for the members of the group and a "Group Profile and Proposal," which outlines composition of the group, a durable solution and resettlement needs analysis, challenges and obstacles to group processing, and logistical and resource constraints. Through this simplified methodology thousands of refugees in need of a durable solution can be submitted at a time. The group methodology has been key not only to enable resettlement countries to meet their targets, but also to resettle some protracted refugee populations such as groups of Somalis in Kenya, Myanmar refugees in Thailand, and refugees from Bhutan in Nepal. Through group processing and by seeking out additional funding and staffing, UNHCR was able to increase submissions above the number of places made available by resettlement states.

While increasing its submissions, UNHCR simultaneously changed its approach to more accurately identify resettlement needs. Each UNHCR operation was required to undertake an annual comprehensive assessment of resettlement needs uninfluenced by the availability of resettlement spaces. Following this approach, overall identified resettlement needs increased from 77,824 for $2004^{32}$ to 958,429 for 2015.33
Table 1. UNHCR annual resettlement submission to all countries

\begin{tabular}{lr}
\hline Year & Submissions \\
\hline 2003 & 35,202 \\
2004 & 39,506 \\
2005 & 46,260 \\
2006 & 54,182 \\
2007 & 98,999 \\
2008 & 121,177 \\
2009 & 128,558 \\
2010 & 108,042 \\
2011 & 91,843 \\
2012 & 74,835 \\
2013 & 93,226 \\
2014 & 103,890 \\
\hline
\end{tabular}

Sources: Figures for 2003 and 2004 generated from UNHCR Resettlement Statistical Database Portal, http://www.unhcrwashington.org/rststat. Figures for 2005 to 2014 from UNHCR, UNHCR Refugee Resettlement Trends 2015 (Geneva: UNHCR, 2015), 24.

This revised approach made it clear that global resettlement needs were far more than the number of resettlement places available. Despite an increase in the number of countries participating in resettlement, the number of resettlement spaces made available for UNHCR submissions increased from 50,000 to only 80,000 between 2004 and 2011. ${ }^{34}$ Given the obvious gap between needs and spaces, UNHCR continues to advocate for the availability of more places and for simplification of selection processing, and has kept its submissions linked closer to the number of resettlement spaces, as opposed to resettlement needs.

UNHCR stopped increasing the number of overall submissions in 2010 because resettlement countries were not keeping pace. In fact UNHCR began consciously reducing its resettlement submissions, recognizing that the backlogs created when resettlement departures do not keep pace with submissions would lead to problems of managing expectations and serious frustrations among the refugee population identified for resettlement.

\section{Evolution of Canadian Resettlement since the Indochinese Movement}

While Canadian resettlement already had a long history of involving faith communities and ethno-cultural groups, the 1976 Immigration Act created the private sponsorship program as a new mechanism for individuals to become involved in resettling refugees that was separate from the government-assisted (GAR) program. This mechanism 
enabled Canadians and permanent residents to come together to sponsor refugees, initially as individual "groups of five." A few months later, to facilitate and promote increased private sponsorship, the government developed and began signing Master Agreements (later renamed Sponsorship Agreements) with incorporated organizations. 35 These organizations, initially mainly faith groups, serve as financial guarantors, enabling the organization and its constituent groups to apply to sponsor a refugee(s) without having to demonstrate the financial capability for each individual application as required of a Group of Five.

When the global Indochinese appeal was launched, the government collaborated with advocates in civil society concerned about the plight of the Indochinese refugees. Together they used the private sponsorship program as the catalyst for Canada's large-scale response to the crisis. Canada effectively used a matching gift model that the government often uses to respond to humanitarian emergencies through which the government commits to match the dollars donated by the public. For the Indochinese, the government offered a one-to-one match of resettlement spaces, committing a national GAR spot for every Indochinese refugee sponsored by a private sponsoring group (regardless of whether by a Group of Five or through a Master Agreement). ${ }^{36}$ The resulting private sponsorship response far exceeded initial government expectations, but the commitments were met, resulting in the largest resettlement of any single group to Canada. While this model established that privately sponsored refugees should be "additional" to government commitments, which became core to the motivation for the private sponsorship program, it also used the private sponsorship program as a key part of Canada's national response to the Indochinese refugee crisis.

The Immigration Act introduced eligibility and admissibility (security, medical, and criminal screening) requirements for resettlement. The creation of the Indochinese Designated Class in the regulations helped make it easier for Canadian officials to find Indochinese refugees eligible for resettlement to Canada. The definition of the Indochinese Designated Class was

a class of persons the members of which (a) are citizens or habitual residents of a country listed in the schedule, (b) have left their country of citizenship or former habitual residence subsequent to April 30, 1975, (c) have not become permanently resettled, (d) are unwilling or unable to return to their country of citizenship or former habitual residence, (e) cannot avail themselves of the protection of any other country, and (f) are outside Canada and seeking resettlement in Canada. 37
This test of having simply left their country and being unwilling or unable to return to Vietnam and having no other solution was much less stringent than determining whether the individual met the Convention Refugee definition. This made the eligibility assessment of Indochinese refugees much easier for Canadian officials and greatly increased the likelihood of acceptance. As the Canadian criteria effectively matched the prima facie status given to Vietnamese refugees up until the time of the CPA, submissions to Canada were simplified, and the risk of large numbers being refused resettlement admission was minimized. Statistics from the time show heavy reliance on the designated class for selection of Indochinese refugees. From 1978 until 1994, 136,951 Indochinese were resettled, of which 129,105 were selected under the Indochinese Designated Class and only 7,846 as Convention Refugees. ${ }^{38}$ In fact it was not until 1992 when the CPA (which required as a precondition for resettlement that the person be found to be a Convention Refugee) was well in place, that the number of Vietnamese selected as Convention Refugees exceeded the number selected under the Indochinese Designated Class. ${ }^{39}$ Reliance on the designated classes to meet Canadian resettlement targets was part of a larger trend. The majority of persons resettled to Canada came under the designated classes for every year between 1979 and 1992.40 The end of this trend may also reflect the fact that by the end of this period, the Cold War was over ${ }^{41}$ and the CPA was well established.

The political changes occurring with the end of the Cold War necessitated a review of Canada's designated classes, and by 1994 proposals were developed as a result of national immigration consultations. As the Immigration Act of 1976 brought transparency and introduced independent criteria for the selection of who was to be resettled as a Convention Refugee, the changes to the designated classes established transparent independent criteria for selecting persons who may not meet the refugee definition but were in "refugeelike" situations, ${ }^{42}$ in place of requiring the political approval to create or dissolve each individual designated class. The required regulatory changes came in 1997, replacing the previous designated classes with the Country of Asylum Class and the Source Country Class under the Humanitarian Designated Classes Regulations. Selection under the Country of Asylum Class required, among other things, that an applicant "has been and continues to be serious and personally affected by civil or armed conflict or a massive violation of human rights in the immigrant's country of citizenship or of habitual residence." 43 The definition was also limited to persons who were privately sponsored or had the financial ability to be self-supporting upon arrival in Canada. 
Although regulatory changes were implemented in 1997, pressures to further revamp Canadian resettlement continued until 2002, when the IRPA came into effect. The most prominent was the Immigration and Legislative Review, whose report recommended revamping the protection framework in Canada. Among its recommendations was that resettlement should prioritize those "most vulnerable and those most in need." Furthermore it stated, "There should be no requirement that applicants be likely to establish themselves successfully in Canada."44 While the government did not adopt the bolder recommendations from the report, including that Canada should establish a single protection system with a single protection agency covering overseas and in Canada, the government did commit to "a more responsive resettlement program" 45 by

- Shifting the balance toward protection rather than the ability to settle successfully in selecting refugees;

- Establishing procedures that will allow members of an extended refugee family to be processed together overseas and, where this is not possible, providing a mechanism for the speedy reunion of families;

- Working more closely with non-governmental organizations in identifying, pre-screening and resettling refugees; and

- Ensuring the immediate entry into Canada of urgent protection cases. 46

During this period leading up to the new Act, a number of forums/consultations on resettlement influenced the development of IRPA and the resulting regulations, and were part of a slow series of incremental shifts to Canadian resettlement. 47

One example was the International Symposium on the Resettlement of Women at Risk hosted by Citizenship and Immigration Canada (CIC) and UNHCR in Toronto in 1998. Among the recommendations was that "resettlement countries should expedite processing of emergency cases in order to reduce protection risks." 48 This initiative, along with the existing impetus from the legislative review, was the foundation for the Urgent Protection Program Pilot launched in 2000.

The Immigration and Refugee Protection Regulations introduced significant changes into Canada's resettlement framework, changes that reflected the shift towards protection. The three categories remained-Convention Refugees Abroad Class, Country of Asylum Class, and Source Country Class-with the last two classes renamed the Humanitarian-Protected Persons Abroad classes. To facilitate family reunification, a "one year window" program was created, enabling dependent family members of resettled refugees in Canada to be resettled under the same program if they submitted an application at a Canadian mission within one year of their family member's arrival in Canada.
A key change was the removal of direct access to a Canadian mission to request resettlement, placing increased importance on UNHCR's resettlement submissions. The regulations introduced a requirement that a person being resettled be "referred" to Canada. 49 Thus, in order to be resettled a person had to be referred by:

- UNHCR

- Another (designated) "Referral Organization"

- A private sponsor (i.e., already has a private sponsorship)

- A foreign state with which Canada has an agreement.50

While the ability to successfully establish remained in Canada's regulations as a requirement for resettlement, the regulations introduced two exemptions to respond to refugees whose protection needs effectively trumped this concern. The exemptions are for refugees determined by a foreign service officer to be in "urgent need of protection" or "vulnerable."

"Urgent need of protection" means, in respect of a member of the Convention refugee abroad, the country of asylum or the source country class, that their life, liberty or physical safety is under immediate threat and, if not protected, the person is likely to be

(a) killed

(b) subjected to violence, torture, sexual assault or arbitrary imprisonment, or

(c) returned to their country of nationality or of their former habitual residence. ${ }^{51}$

"Vulnerable" means, in respect of a Convention refugee or a person in similar circumstances, that the person has a greater need of protection than other applicants for protection abroad because of the person's particular circumstances that give rise to a heightened risk to their physical safety. ${ }^{52}$

These definitions gave Canadian officers the means to surmount the ability to establish requirement ${ }^{53}$ for refugees with desperate protection needs. It also reflected a trend to be more lenient when applying the ability to establish requirement. This view can be seen in the operational manuals of the time, which urged visa officers to apply ability to successfully establish with a three- to five-year timeframe in mind, ${ }^{54}$ so there was already a focus on leniency in applying this requirement. Officers were therefore given tools to better respond to UNHCR referrals, reducing the prospect of refusals of applicants on non-protection related grounds. Since UNHCR's resettlement criteria are guided by protection and/or durable solution need, there is no consideration of the applicant's ability to establish in a resettlement country as a condition for a resettlement referral. ${ }^{55}$ If Canada applied the ability to establish criterion stringently, it could undermine the protection function of the program by moving 
the focus away from those who need resettlement most. In addition, at an operational level, high numbers of refusals means a waste of resources for both UNHCR and Canada. A similar important development in selecting refugees on the basis of their protection needs was removal of the excessive medical demand as a barrier for the selection of refugees for resettlement.

The regulatory change also facilitated creation of the Urgent Protection Program (UPP). While not in the regulations, Canada's overseas processing manual explains that Canadian missions or visa posts should ensure that UPP cases receive immediate attention. ${ }^{56}$ Canada has set out processing benchmarks for missions, advising that upon receiving an emergency submission from UNHCR, the receiving Canadian mission should inform UNHCR within 24 hours whether or not it can process the application under the UPP. If it confirms that it can do so, it should try to complete the applicant's processing (including departure) within five days. Although Canadian missions have seldom met these timelines, the UPP established a structure for Canada to process UNHCR emergency submissions, including expedited security reviews in Ottawa, in order to facilitate the processing. From 2010 to 2013, 87 emergency cases arrived in Canada. ${ }^{57}$

One development established outside the regulations was a means for Canada to undertake group processing of refugees for resettlement. This model was developed specifically to respond to "the very practical operational difficulties facing Canada in terms of securing sufficient referrals from UNHCR and matching limited resources and resettlement spaces to those refugees most in need of Canada's protection through resettlement." 58

Given its concern about ensuring sufficient referrals, Canada began testing group processing as a selection model. In 2003 UNHCR provided detailed profiles of two populations in the Dadaab refugee camps-a group of Sudanese Christians and Somalis from the Madhiban clan in Kenyafor a group processing pilot. For CIC to facilitate processing of the group, they established two key components: "first, that the members of the identified group were prima facie Convention refugees; and second, that the prima facie refugees were deemed 'vulnerable' and therefore, according to our Regulations did not need to meet the ability to establish criteria." 59

While this group referral project was organized in cooperation with Australia, the subsequent group-processing referrals were organized with a much larger group of resettlement states. The identification of the group for the pilot in Kenya involved UNHCR consulting locally with the Canadian High Commission in Nairobi before making the referral. While Canada was undertaking this pilot, UNHCR developed its procedure and forms for making a group referral under the group methodology referred to earlier. This format became the basis for a number of group referrals to Canada made over several years, including Myanmar refugees from the Thai border camps of Mae La Oon and Mae Ra Ma Luang and, subsequently, refugees from Bhutan in Nepal.

The efficiency of group processing for Canada was apparent. Once Canadian officials effectively accepted the UNHCR referral at headquarters, the missions reviewing the related registration documents undertook preparatory work, enabling teams of Canadian officials to visit the camps and select hundreds of refugees for resettlement within a few days. Working from the premise that the refugees referred were eligible for resettlement, interviews focused only on verification of the refugees' identity and membership in the group and admissibility to Canada. In 2011 group processing of Bhutanese refugees made up 20 per cent of those resettled to Canada under the GAR. ${ }^{60}$

Canada also used simplified processing for select refugee populations. A few years after IRPA's passage, Canada resettled a large number of Afghan refugees from a number of countries in Central Asia through a simplified submission process that effectively involved UNHCR forgoing preparing an individual RRF but instead sharing registration information and completing a Canadian permanent resident application for each Afghan refugee.

UNHCR's guidelines on the protection needs of select refugee populations also helped Canada formulate guidance for Canadian missions on the eligibility of select refugee populations, which became the basis for high acceptance rates. For example, Canada's resettlement of large numbers of Iraqis in the years following UNHCR's Iraqi resettlement appeal on 14 February 2007 was emboldened by UNHCR's December 2006 guidelines on Iraqi protection needs, which included recommendations that "Iraqi asylum-seekers from Southern and Central Iraq should be favourably considered as refugees under the 1951 Convention relating to the Status of Refugees."61 International protection guidance has since allowed Canadian officers to "concentrate on the review of GAR on the basis of admissibility (i.e. does the GAR pose a security or health risk) rather than on the basis of eligibility (is the GAR an eligible refugee under Convention definitions),"62 also resulting in higher acceptance rates.

Canada's efforts to adjust its resettlement program through policy and operational measures made it more coherent with UNHCR identified resettlement needs. The positive result is that Canada's acceptance rate of UNHCR referrals is generally around 90 per cent. ${ }^{63}$ However, UNHCR emergency referrals do not fare as well, ranging from 55.8 to 70 per cent from 2010 to $2012,{ }^{64}$ although this percentage is consistent with a lower 
global acceptance rate for emergency cases among overall submissions to all resettlement countries. ${ }^{65}$

The government introduced a new round of resettlement changes in 2010, while overhauling its immigration programs. In March 2010, Canada pledged to expand resettlement by 20 per cent by creating an additional 2,000 private sponsorship spaces and 500 GAR spaces (along with a 20 per cent increase in Resettlement Assistance Program funding) upon passage of the government's reforms to the asylum system. ${ }^{66}$ There were subsequent regulatory and policy changes. One was the elimination of the Source Country Class, which CIC argued was "inefficient, [and] unresponsive to evolving protection needs" and that its removal would allow for more referral spaces for UNHCR's resettlement needs at a time when UNHCR was appealing for more spaces. ${ }^{67}$ Nevertheless, despite the 2010 pledge to expand resettlement, the 2012 budget overtook this commitment, and instead led to the creation of the Blended Visa Officer Referred (BVOR) program, a hybrid program matching UNHCR identified cases to private sponsoring groups, and dividing responsibility for the financial support between the government and the sponsors. This enabled the government to reduce the GAR program without reducing the potential number of UNHCR referral spots at a time when UNHCR was appealing for additional resettlement spaces to respond to the global resettlement need.

At the same time the government began responding to concerns from service providers that the changes resulting from IRPA (elimination of the excessive medical demand and the focus away from ability to establish) was resulting in increased demands on settlement services. ${ }^{68} \mathrm{CIC}$ proposed to refocus Canada's GAR resettlement program upon a few populations through multi-year commitments, which would ideally assist service providers in their integration program planning while also trying to limit the number of "high medical needs" 69 cases referred by UNHCR. The goal was to move Canadian resettlement selection from a global resettlement program with a few multi-year com mitments that were focused primarily on protection needs built around two programs (GAR and PSR). In its place the government proposed three program streams (GAR, PSR, and BVOR) with "targeted, multi-year commitments" and a "focus on protection need and settlement capacity."70

2015 multi-year resettlement commitments include:

- 4,00o Iraqis out of the Middle East by 2015, towards an overall commitment of 20,000 Iraqis, along with an additional commitment of 3,00o Iraqis in 2015;

- 1,000 Bhutanese out of Nepal in 2015, towards an overall commitment of 6,500 Bhutanese;

- 5,000 refugees out of Turkey between 2013 and 2018 (Iraqis and Iranians in the short term);
- 10,000 Syrians from the region in 2015-17;

- 900 Colombians out of Ecuador between 2014 and 2017;

- 4,000 Eritreans out of Eastern Sudan and Ethiopia between 2014 and 2019; and

- 2,500 Congolese out of Tanzania and Burundi between 2015 and $2018 .^{71}$

Another important aspect of the multi-year commitments was the engagement of the political level in determining where Canada would commit. ${ }^{72}$ While all of Canada's commitments made are linked to UNHCR identified needs, Canada has not responded to every resettlement need identified by UNHCR.

While the makeup and number of resettled refugees has been redistributed among programs, the one area of growth in resettlement has been outside the refugee stream through the development of "public policy" spaces. While the numbers selected through this mechanism are not entirely clear, ${ }^{73}$ the target for 2015 was $900-1,200$ persons. Public policy spaces are created under the power of the minister to grant "permanent resident status or an exemption from any applicable criteria or obligations of this Act if the foreign national complies with any conditions imposed by the Minister and the Minister is of the opinion that it is justified by public policy considerations." 74 This tool has been used for persons from a variety of populations including Afghan interpreters who worked with Canadian forces, Tibetans residing in Arunachal Pradesh, and a group of Haitian victims of violence referred by UNHCR from inside Haiti. Also included under public policy have been "stateless" Vietnamese from Southeast Asia, some of whom apparently date back to the time of the CPA, and/or including persons who have married nationals in other countries in Southeast Asia.

\section{The Private Sponsorship Program Evolution}

As noted at the outset, the private sponsorship program helped facilitate Canada's tremendous response to the Indochinese movement. The Private Sponsorship Program, like resettlement policy overall, has undergone its own evolution since the Indochinese movement. While the timing of the program's creation was fortuitous, also key to the overwhelming response was the political will and the determination of advocates to engage not only the government but ordinary Canadians in order to organize and form sponsorship groups. While the movement was effectively implementing government policy, it also established "additionality" as a component of the private sponsorship program. Every Indochinese refugee sponsored by a private group ultimately resulted in an additional refugee resettled to Canada by the government as a result of the matching formula the government put in place. 
Following the high of approximately 35,000 refugees privately sponsored in $1979-80,75$ the program hovered around 3,800-5,800 privately sponsored refugees admitted each year until $1987,{ }^{76}$ and experienced another surge in the late 1980s. This surge reflected the resettlement of large numbers under the East European Self-Exiled Designated Class, particularly individuals from Poland who were sponsored by Polish ethnic groups and faith communities in Canada. This was part of a general trend of fewer private sponsorship cases being identified by visa officers, with sponsors instead responding directly to requests for resettlement from persons overseas who were either identified by family or friends in Canada or from partner organization overseas. By the end of the 1980 os both the government and NGos rec ognized strains on the private sponsorship program. "The dramatic increase in numbers (from 7,621 in 1987 to 21,212 in 1989) challenged the government's planning and management systems. The program that began as an imaginative and flexible partnership between the private sector and the government was, by 1990, beginning to experience mistrust on both sides."77

In 1990 the government undertook a comprehensive review of the PSR program..$^{8}$ While there were a subsequent number of reports, recommendations, and new forums for consultation during the 1990s, this period also demonstrated the program's flexibility to respond to time-limited special initiatives. These include Project Focus Afghanistan implemented with the Ismaili community between 1994 and 1998, the Special 3/9 Sponsorship Pilot Program in response to a UNHCR appeal for resettlement of refugees from the former Yugoslavia, and the Sierra Leone Blended Sponsorship Pilot-with the government providing the sponsored refugees four months' financial assistance and the sponsors providing the remaining eight months'. However, the most significant initiative was the sponsorship of 5,000 evacuated refugees from Kosovo in 1999. The media attention and outpouring of willingness to assist Kosovar refugees was the largest public involvement in resettlement since the time of the Indochinese. All of these special initiatives in the 1990s involved slight adjustments to the private sponsorship program, which spoke to its agility and the willingness of the volunteers involved to respond to new needs and realities.

The following decade saw technical changes in the processing of sponsorship submissions, but the same issues that had plagued the private sponsorship program, including slow processing and backlogs, continued to concern sponsors.

CIC began proposing in 2006 that sponsors voluntarily control the number of applications submitted at missions, so that missions could clear out their backlogs, since the number of sponsorship applications in the system far exceeded mission targets. ${ }^{79}$ However, in 2011 the government imposed caps on private sponsorships at the Canadian High Commission in Nairobi, where the mission backlogs were most acute, and in 2012 the government enforced limitations by placing caps on overall submissions by Sponsorship Agreement Holders. The government also implemented regulatory changes in 2012 restricting groups of five to sponsoring only recognized refugees, ${ }^{80}$ thus effectively limiting their submission levels. Despite efforts to control backlogs and processing delays, this problem continued, part of which was associated with the initial establishment of a central processing office for private sponsorship applications.

The private sponsorship program received increased political attention after the 2006 election. While the government worked to control the number of new applications, the refugee reform package led to increased annual targets for the private sponsorship program. At the same time, the private sponsorship program was increasingly included as part of the government's overall response to refugee needs. While private sponsors on their own initiative were involved in sponsoring Palestinians ex-Iraq ${ }^{81}$ in response to UNHCR's appeal, private sponsorships were Canada's response to UNHCR's resettlement appeal for the refugee population displaced by the "Arab Spring" in Libya who fled to Tunisia. Canada's multi-year resettlement commitments incorporate private sponsorship admissions. For example, Canada's pledge to resettle 1,30o Syrian refugees in 2013-14 committed private sponsors to resettle 1,100 of this total, with the national GAR program allocating spaces for only 200 Syrians. ${ }^{82}$ Private sponsorships were also a part of Canada's January 2015 pledge to resettle 10,00o Syrian refugees between 2015 and 2017. In addition, the BVor program was founded on the expectation that private sponsors take on part of the cost of resettling refugees referred by UNHCR.

\section{Legacy of the Indochinese Movement and Today's Challenges}

Since the time of the Indochinese movement, resettlement has become much more complex and resource-intensive, and has also gained international legitimacy as it has become more responsive to global protection needs. The number of countries committed to regularly resettling refugees referred by UNHCR continues to grow. Despite the fact that only a small percentage of refugees are resettled each year, resettlement has been given greater importance as a legal migration pathway in response to some of the greatest challenges facing the international protection regime. The most recent example, at the time of writing, is UNHCR's goal of resettling 10 per cent of the Syrian refugee population. ${ }^{83}$

Canada has remained a key resettlement player over successive governments. The changes introduced with the 
adoption of IRPA in 2002 recognized the humanitarian nature of refugee resettlement, diminishing the need for refugees to demonstrate that they could "establish" themselves, and no longer excluding refugees on the basis of "excessive medical demands." In effect, Canada's post-IRPA selection strategies mirrored UNHCR initiatives to respond more effectively to identified resettlement needs. However, while selection barriers diminished, this period saw the beginning of increased attention to security admissibility requirements.

Yet the removal of barriers that represented a more "open door" policy for high-needs cases following IRPA led to internal concerns about managing the number of resettlement cases with high medical or other settlement needs.

One key to the Indochinese movement's operational success was the simplicity of eligibility assessments and processing. In recognition of the global value of this durable solution, there is a current push to regain some of this simplicity. UNHCR continues to engage with states to simplify resettlement submissions, given the amount of work that can go into documenting a single submission. ${ }^{84}$ Greater simplicity is required if this solution is to be expanded significantly.

Although the surge of public interest in assisting refugees in the latter half of 2015 raised the profile of private sponsorship once again, the private sponsorship program has continued to engage Canadians in the resettlement of refugees since the Indochinese movement. Through it, hundreds of thousands of refugees have been resettled to Canada. The Conservative government made changes to bring the program into greater coherence with the government's overall direction on resettlement. It more directly linked the program to Canada's choice of priority populations and responses to current resettlement needs, similar to the Indochinese era. However, these adjustments, along with efforts to manage the backlogs that have crippled the private sponsorship program, also partially compromised the additionality value that the program brought to Canada's collective resettlement effort.

Even prior to the 2015 federal election campaign, resettlement had become more visible in political debates, and the political level of government appears more engaged in resettlement's direction and management. It is recognized that involvement of the political leadership during the Indochinese movement enabled the creation of the Indochinese Designated Class and, more importantly, sped approval to increase Indochinese arrivals. Canada's move away from relying on designated classes to select refugees for resettlement in the 1990s was nevertheless welcome, since this approach, along with the changes surrounding IRPA, made Canada's resettlement programs more responsive to needy refugees around the world instead of focused on select populations.
However, starting in the years of the Conservative government, Canada's focus on multi-year commitments to select populations allows the political level to play an increased role in the decisions on who should be resettled, as it decides which UNHCR identified needs to prioritize. The former government also created a public policy component to Canada's overall humanitarian program, a new area in resettlement through which the political level is able to offer resettlement to a population that does not meet the refugee definition.

Lessons from the Indochinese experience remain relevant to this day. It is a foundation for contemporary resettlement and offered a dramatic demonstration that the public can be a driving force for refugees. This article has sought to provide an overview of the evolution of UNHCR's and Canada's resettlement policies between 1978 and mid-2015 so as to recognize the key changes and interplay between the two. This is not to suggest that there are no other influences in broader debates about refugee protection, migration, and Canada's response recognizing the changing global environment.

Resettlement, by its voluntary nature, reflects elements of diplomacy, strategy, coordination, and cooperation. This extends beyond UNHCR and includes all resettlement countries. Much of this interrelationship remains unknown outside of this circle. Also unknown for those outside government is how much security considerations affect resettlement operations in eligible and operational locations.

This article effectively ends at the beginning of a new chapter in Canadian resettlement. Interestingly the Indochinese movement of the late 1970s appears to be the closest parallel to the resettlement of Syrians taking place in 2015 and 2016. It is not yet clear what the "new normal" will be for Canada's resettlement program, recognizing that Canada's 2016 resettlement admission target of 44,800 persons ${ }^{85}$ is the largest since the Immigration Act of 1976, and the government has not indicated its resettlement admission plans at the time of writing for 2017 and beyond. While much has changed, there are key parallels and contrasts between the Indochinese and Syrian resettlement movements in a variety of areas, including scale, political leadership, public opinion, public engagement, and overseas and domestic operational practices, which will no doubt be the subjects of future examination. The reality that the private sponsorship program, as a model, is the subject of increased interest ${ }^{86}$ shows that the lessons of the Canadian resettlement experience are not simply important for Canada but for other countries as well.

\section{Notes}

1 Ninette Kelley and Michael Trebilcock, The Making of the Mosaic: A History of Canadian Immigration Policy (Toronto: University of Toronto Press, 2000), 390. 
2 United Nations High Commissioner for Refugees (hereafter UNHCR), UNHCR Resettlement Handbook, rev. ed. (Geneva: UNHCR, 2011), 3.

3 Courtland Robinson, Terms of Refuge: The Indochinese Exodus and the International Response (New York: Zed Books, 1999), app. 2, 295.

4 Ibid.

5 Courtland Robinson, "The Comprehensive Plan of Action for Indochinese Refugees, 1989-1997: Sharing the Burden and Passing the Buck," Journal of Refugee Studies 17, no. 3 (2004): 320.

6 Robinson, Terms of Refuge, 127.

7 For an analysis of the CPA, see ibid., 187-226.

8 Gil Loescher and James Milner, "Protracted Refugee Situations: Domestic and International Security Implications," Adelphi Paper no. 375 (Basingstoke, uk: Routledge for the International Institute for Strategic Studies, 2005), 72.

9 John Fredriksson and Christine Mougne, "Resettlement in the 1990's: A Review of Policy and Practice" (Geneva: UNHCR, 1994), 6, http://www.unhcr.org/3ae6bcfd4.html.

10 Thais Bessa, "From Political Instrument to Protection Tool: Resettlement of Refugees and North-South Relations," Refuge 26, no. 1 (2009): 94.

11 Fredriksson and Mougne, "Resettlement in the 1990's," 7.

12 Raphael Girard, "Designated Classes: A Regulatory Device to Target Humanitarian Resettlement Programs," Canadian Immigration Historical Society, 1 January 2005, http://cihs-shic.ca/2005/o1/designated-classes/.

13 Howard Adelman and Naomi Alboim, "Draft: A Proposed Revised Refugee Resettlement Policy for a New Age" (2014), 3-5.

14 Fredriksson and Mougne, "Resettlement in the 1990's," 5. 15 Ibid., 8.

16 UNHCR, Office of Internal Oversight Services (OIOs), Investigation into Allegations of Refugee Smuggling at the Nairobi Branch Office of the Office of the United Nations High Commissioner for Refugees (Geneva: OIOs, 2001).

17 Ibid., 1.

18 UNHCR, Global Consultations on International Protection, "Strengthening and Expanding Resettlement Today: Dilemmas, Challenges and Opportunities" (Geneva: UNHCR, 2002), 5.

19 UNHCR, Annual Tripartite Consultations on Resettlement, "Agenda Item $3 \mathrm{f}$ Information Note: Baseline Standard Operating Procedures on Resettlement" (Geneva: UNHCR, 2007), http://www.refworld.org/docid/46822cffd.html.

20 UNHCR, UNHCR Resettlement Anti-Fraud Plan of Action (Geneva: UNHCR, 2004).

21 Refugee Council UsA, The Impact of the Material Support Bar: Us Refugee Admissions Program for Fiscal Year 2006 and 2007; Recommendations of Refugee Council USA (Washington: Refugee Council UsA, 2006), 7, http://www. rcusa.org/uploads/pdfs/RCUSA20o6finpostbl-w.pdf.
22 Immigration and Refugee Protection Regulations, SOR/2002-227, 34(1)(f), http://laws-lois.justice.gc.ca/eng/ regulations/sOR-2002-227/page-1.html.

23 Ibid., 34(1)(a).

24 Canadian Council for Refugees, Eritrean Canadian Community Centre of Metropolitan Toronto, HidmonaEritrean Human Rights Group in Manitoba, Holy Trinity Eritrean Orthodox Church in Toronto, Meftih Eritrea Community Newspaper, Qalna Eritrean Human Rights Group-Toronto, From Liberation to Limbo: A Report on the Impact of Immigration Security Inadmissibility Provision on the Eritrean Community in Canada, and Recommendations for Reform, Submitted to the Ministers of Citizenship and Immigration and Public Safety (Montreal: Canadian Council for Refugees, April 2010), 11.

25 David Kenner, "If You're a Refugee Dreaming of Coming to America, Don't Come to Lebanon," FP Dispatch, 8 December 2015, http://foreignpolicy.com/2015/12/o8/ if-youre-a-refugee-dreaming-of-america-dont-come-tolebanon/.

26 The six Agenda for Protection goals are to (1) strengthen implementation of the 1951 Convention and 1967 Protocol; (2) protect refugees within broader migration movements; (3) share burdens and responsibility more equitably and build capacities to receive and protect refugees; (4) address security-related concerns more effectively; (5) redouble the search for durable solutions; and (6) meet the protection needs of refugee women and refugee children.

27 UNHCR, "Agenda for Protection," A/AC.96/965/Add.1 (Geneva: UNHCR, 2002), http://www.unhcr.org/3d3e61b84.html.

28 UNHCR, "The Strategic Use of Resettlement: A Discussion Paper Prepared by the Working Group on Resettlement," EC/53/sc/CRP.10/Add.1 (Geneva: UNHCR, 2003).

29 For an examination of "warehousing" refugees, see Merrill Smith, "Warehousing Refugees: A Denial of Rights, a Waste of Humanity," World Refugee Survey 2004 (Arlington, vA: us Committee for Refugees, 2004), http://refugees. org/wp-content/uploads/2015/12/Warehousing-RefugeesCampaign-Materials.pdf.

30 us Department of State, us Department of Justice, us Department of Health and Human Services, Report to the Congress on Proposed Refugee Admissions for Fiscal Year 1995 (Washington: Government of the United States, 1994), 19. This increase can be seen in UNHCR resettlement submission statistics. In 2003, 20,378 persons were referred, while in 201554,218 were referred. (The highest number of referrals in that period was in 2009 with 102, 586). Statistics generated from UNHCR Resettlement Statistical Database Portal, http://www.unhcrwashington.org/rststat.

31 The Resettlement Registration Form is the format by which UNHCR submits individual resettlement cases.

32 UNHCR, UNHCR Projected Global Resettlement Needs (Geneva: UNHCR, 2014), 2. 
33 UNHCR, UNHCR Projected Global Resettlement Needs, 2015 (Geneva: UNHCR, 2014), 9.

34 UNHCR, 2012 Annual Tripartite Consultations on Resettlement, "UNHCR Discussion Note: The Effective Use of Resettlement Places: Trends and Concerns Related to the Capacity of the Global Resettlement Program" (Geneva: UNHCR, 2012), 1.

35 Barbara Treviranus and Michael Casasola, "Canada's Private Sponsorship of Refugees Program: A Practitioner's Perspective of Its Past and Future," Journal of International Migration and Integration 4, no. 2 (2003): 184.

36 Ibid.

37 Office Consolidation, "Indochinese Designated Class Regulations," http:/cihs-shic.ca/wp-content/uploads/ 2015/03/Indochinese-Designated-Class-Regulations-2.pdf.

38 Canada selected an additional 7,708 Indochinese refugees between 1975 and 1978, who arrived under the previous Act when there was no Convention Refugee or Designated Class designation. CIC, International Refugee and Migration Policy Branch, March 1995.

39 Ibid.

40 Canadian Council for Refugees, "Resettlement 1979-1996: Statistical Information” (November 1996), http://ccrweb. $\mathrm{ca} /$ sites/ccrweb.ca/files/static-files/stat1a.htm.

41 Canada also had a Self-Exiled Designated Class focusing on Eastern Europeans, and a Latin American Political Prisoners and Oppressed Persons Designated Class that was renamed the Political Prisoners and Oppressed Persons Class in 1982.

42 CIC, "Operations Memorandum Refugee and Humanitarian Resettlement Program: In Canada" (Ottawa: Government of Canada), 7.

43 "Humanitarian Designated Classes Regulations," Canada Gazette 131, no. 9 (30 April 1997).

44 See recommendation 88 of CIC, Not Just Numbers: A Canadian Framework for Future Immigration, Immigration Legislative Review (Ottawa: CIC, 1997), 87.

45 CIC, Building on a Strong Foundation for the 21st Century: New Directions for Immigration and Refugee Policy and Legislation (Ottawa: CIC, 1998), 43.

46 Ibid.

47 Michael Casasola, "Current Trends and New Challenges for Canada's Resettlement Program," Refuge 19, no. 4 (2001): 76.

48 CIC and UNHCR Workshop Meeting New Challenges: Evolving Approaches to the Protection of Women at Risk, Summary of Discussions and Recommendations (Ottawa: CIC and UNHCR, 1998), 4.

49 Immigration and Refugee Protection Regulations, SOR/2OO2-227, S. 140.3 (1).

50 Ibid.

51 Ibid., s. 138.

52 Ibid.

53 Ibid., s. 138(1)(g).
54 CIC, OP 5 Overseas Selection and Processing of Convention Refugees Abroad Class and Members of the HumanitarianProtected Persons Abroad Classes (CIC: Ottawa, 2009), 66.

55 UNHCR, Resettlement Handbook, rev., 245.

56 Ibid., 29.

57 UNHCR, "UNHCR Emergency Submissions to Canada 20102014," PowerPoint presentation, Gatineau, CCR Fall Consultation 2014, http://ccrweb.ca/en/system/files/unhcremergency-submissions-to-canada-2010-2014.pdf.

58 cIC, Resettlement Division, Refugees Branch, Group Processing Project Evaluation Final Report (Ottawa: CIC, 2005), 3.

59 Ibid., 4.

60 CIC, Evaluation Division, Evaluation of Government Assisted Refugees (GAR) and Resettlement Assistance Program (RAP) (Ottawa: CIC, 2011), xii.

61 UNHCR, "UNHCR Return Advisory and Position on International Protection Needs of Iraqis outside of Iraq" (Geneva: UNHCR, 2006), 3, http://www.refworld.org/pdfid/46371aa72 .pdf.

62 CIC, Evaluation Division, Evaluation of GAR and RAP, 13.

63 UNHCR Canada, "Emergency Submissions to Canada 2010-2012: Observations and Trends Analysis," 2013 Annual Tripartite Consultations on Resettlement (Ottawa: UNHCR, 2013), 6.

64 Ibid.

65 In 2012 UNHCR normal submissions averaged an acceptance rate of 88.8 per cent and emergency submissions averaged a 74.4 per cent. UNHCR, UNHCR Global Resettlement Statistical Report 2012 (Geneva: UNHCR, 2012), 12.

66 CIC, Backgrounder: More Support for Resettled Refugees (Ottawa: CIC, 2012).

67 CIC, Repeal of the Source Country Class of Humanitarian-Protected Persons Abroad, Operational Bulletin 346 (Ottawa: CIC, 7 October 2011).

68 CIC, Evaluation Division, Evaluation of GAR and RAP, 28.

69 CIC presentation, "Refugee Resettlement: Future Directions," Fall 2012, slide 6.

70 Ibid., slide 5 .

71 This is compiled from the Refugee Sponsorship Training Program, "Multiyear Refugee Resettlement Commitments," http://www.rstp.ca/en/refugee-sponsorship/ latest-policy-program-update/multiyear-refugee-resettlement-commitments/; and Global Affairs Canada, "Helping to Protect the World's Most Vulnerable," news release, 7 January 2015, http://news.gc.ca/web/article-en . do? nid $=918349 \&$ \& ga $=1.28590335 .250123850 .1460758429$.

Canada had a previous commitment of 1,100 Syrian refugees (200 GAR and 1,100 PSR) in 2013 and 2014.

72 CIC, memorandum to the minister, "Follow-up to Portfolio Briefing on Improving Government Assisted Refugee Outcomes," 12 October 2012; CIC, memorandum to the minister, "Resettled Refugee Populations: Multi-Year Commitments for 2013 and Beyond," 30 October 2012; CIC, memorandum to the minister, "Options for Managing 
Resettled Refugees with High Needs," 11 December 2012; and CIC, "Annex C: Resettled Refugee Populations: MultiYear Commitments for 2013 and Beyond."

73 2013-15 Public Policy spaces are noted in Immigration Levels Plans. For 2012 they are combined with Humanitarian and Compassionate Grounds targets. See CIC, "Notice: Supplementary Information for the 2013 Immigration Levels Plan" (Ottawa: CIC, 5 November 2012), http:// www.cic.gc.ca/english/department/media/notices/noticelevels2013.asp

74 Immigration and Refugee Protection Act, S.C. 2001, c. 27, S. 25.2 .

75 Not exclusively Indochinese refugees.

76 Government of Canada, "Canada-Permanent Residents by Category, 1980-2014," http://open.canada.ca/data/en/ dataset/8cocbfcb-4ea4-44ed-a58a-3fbc9edd8381.

77 Treviranus and Casasola, "Canada's Private Sponsorship of Refugees Program,” 186.

78 Ibid., 187.

79 Debra Pressé, director, Resettlement Cic, letter to Sponsorship Agreement Holders, 3 March 2006, 3.

80 Either by UNHCR or a foreign state "under the rules applicable to the United Nations High Commissioner for Refugees or the applicable laws of the foreign state,"
Immigration and Refugee Protection Regulations, SOR/2002-227, s. 153 (1)(b).

81 "Palestinians ex-Iraq" are Palestinian refugees who had been living in Iraq but were forced to flee Iraq to another state.

82 CIC, "Canada to Resettle 1,300 Syrian Refugees by End of 2014," news release, 3 July 2013.

83 UNHCR, "Background Note: High-Level Meeting on Global Responsibility Sharing through Pathways for Admission of Syrian Refugees" (Geneva: UNHCR, 2016), 1.

84 UNHCR, Working Group on Resettlement, "Simplification of Resettlement Procedures” (Geneva: UNHCR, 2015), 1.

85 Immigration, Refugees and Citizenship Canada, 2015 Annual Report to Parliament on Immigration (Ottawa: IRCC, 2016).

86 Judith Kumin, Welcoming Engagement: How Private Sponsorship Can Strengthen Refugee Resettlement in the European Union, EU Asylum towards 2020 Project Migration Policy Institute Europe (Brussels: Migration Policy Institute, 2015).

Michael Casasola is a resettlement officer at UNHCR Canada. The author may be contacted at casasola@unhcr.org. 